\title{
The 'Silent Dilemma' of Transitional Justice: Silencing and Coming to Terms with the Past in Serbia \\ Jelena Obradović-Wochnik
}

\section{Introduction}

Following the July 2008 arrest of Bosnian Serb leader Radovan Karadžić, indicted for the siege of Sarajevo and crimes against Bosnian Muslims (Bosniaks), author Slavenka Drakulić wrote that 'Serbs live in denial. ${ }^{2}$ This is a resonant representation of 'the Serbs' in practitioner and scholarly transitional justice literature, in which this group is constructed as not just in denial of the past but also indifferent to crimes committed by Serbs against Croats, Bosniaks and Albanians in the 1991-1999 conflicts in the former Yugoslavia. The general public, variously labelled and conflated with 'Serbia' or 'the Serbs,' is seen by transitional justice actors as one obstacle to confronting the past. Whilst the focus of the International Criminal Tribunal for the former Yugoslavia (ICTY) has been prosecuting war criminals, many domestic, civil society initiatives have attempted to change societal attitudes towards the past by organizing publicity campaigns about crimes committed by Serbs aimed at 'broad acknowledgement' ${ }^{3}$ of these crimes. However, as practitioners have noted, the public is generally silent and disengaged from these debates. Marijana Toma, a prominent activist from the Humanitarian Law Centre, recently suggested that the majority of the Serbian public does not know or want to know about the past, which it denies directly or interpretatively. ${ }^{4}$ The silence of the public has also been conceptualized as the 'banality of indifference' and 'hate silence. ${ }^{5}$

Such representations have emerged partly as a result of constructs based on a 'negative' reading of silence, ${ }^{6}$ whereby the absence of 'the public's' voice and participation is understood predominantly as a result of denial of the past. More broadly, this reading can be situated within what Jessica Greenberg identifies as a dichotomic reading of nonparticipation in postsocialist countries, where 'failures' are correlated with 'absences,' such as 'reconciliation, or its absence, [and] political participation, or its absence." Moreover, such readings are diffused through nongovernmental organizations' (NGOs) discourse on the past, whereby transitional justice advocates who often have relatively little empirical engagement with the public continue to speak on its behalf.

The absence of 'ordinary' voices in transitional justice debates in Serbia and the disconnect between the public and practitioners are evident at some transitional justice events. For instance, in May 2011, I attended a discussion in Belgrade organized by NGOs campaigning for a regional truth commission. Although the talks were clearly aimed at a general audience, the audience was composed primarily of activists from Belgrade and Sarajevo, the media and intellectuals. The only audience members not already affiliated with regional activist circles were a handful of students. It was thus a discussion at which experts spoke to other experts about issues on which they broadly agree.

When I visited one of my respondents later that day, I was struck by the disconnect between the activists' reality and that of their intended audience. The respondent, a middle-aged, university-educated public sector employee, would not have been able to attend the discussion as she would have had to leave work early and take two buses, in addition to having to look after her elderly mother and two children. The respondent was also very careful that her private life be enacted primarily within the confines of her immediate neighbourhood. This was a result of difficult experiences in the 1990s, including being physically attacked during anti-Milošević demonstrations, as well as subsequent problems with mental health. During my research in Belgrade, the respondent and I discussed the wars and the violent past. Her feelings about the crimes committed against others were those of revulsion. She expressed acknowledgement of these crimes many times. ${ }^{8}$ Yet, her story and opinions are absent from debates conducted publicly. This disconnect, I argue, is primarily due to transitional justice initiatives in Serbia prioritizing and normalizing public engagement, discussion and acknowledgement as the most visible 'evidence' of the society's 'coming to terms with the past,' to the point of silencing those who do not conform to this approach, ${ }^{9}$ implicitly framing them as 'failures. ${ }^{10}$ This approach rarely considers socioeconomic, cultural and personal limitations to such engagement, and that speaking out is not always possible, or desirable. ${ }^{11}$ 
This article posits that the public is not as silent as it might seem; rather, some narratives are not audible to practitioners of transitional justice. I explore this disconnect through the dynamic of silencing, ${ }^{12}$ suggesting that transitional justice practice can create discourses that disengage audiences and discourage them from speaking. I argue that selective academic engagement - which prioritizes activists' voices whilst neglecting empirical research on audiences 'below' - creates further silence through exclusion, as well as lack of reflection on relationships of power and privilege that may lead to such practices. Further, transitional justice practitioners, concerned with public participation, often fail to consider the contexts that make such participation and speaking (im)possible. ${ }^{13}$

Whilst the article focuses on Serbia, I aim for broader relevance, arguing that transitional justice has a complex relationship with silence. Specifically, I ask if transitional justice practice and discourse create 'silent' subjects. The logic of publicity that drives some mechanisms, such as truth commissions and trials, can be overprioritized, as in Serbia's case, to the point at which silent, nonverbal or performed confrontations with the past are overlooked, misunderstood and thus silenced further. ${ }^{14}$ Fighting against silence is such a deeply entrenched approach of transitional justice that critical reflections on 'silence' are rare. ${ }^{15}$

This article follows Gurminder Bhambra and Robbie Shilliam's assertion that "silence" is an "increasingly pertinent" concept through which to frame and investigate ... contested projects. ${ }^{16}$ This conceptual framework is concerned, in part, with exposing silences and analysing what might constitute silencing. ${ }^{17}$ I use it to explore how transitional justice practice and discourse create inclusions and exclusions, ${ }^{18}$ and whether they can disenfranchise, rather than empower, audiences to speak about violent pasts.

To examine the intersections of transitional justice and silence, the article uses Serbia as a case study. Given its wartime violence, a nationalist and repressive regime until 2000 and subsequent governments' failure to instigate a systematic approach to transitional justice, Serbia is enveloped in several layers of silence and silencing. Regimes have worked to repress public knowledge of atrocities and the past, whilst NGOs have worked to fight against silence. The case illustrates that there are no straightforward relationships between silence and its breakage, and that individuals do not always respond by keeping silent when faced with repression. It also illustrates that silence can be circumscribed by unequal power relationships and practices of exclusion. ${ }^{19}$

These exclusionary practices are exemplified, in Serbia's case, by the repressive Milošević regime, whose drive to suppress the truth about war crimes resulted in what Lynn Thiesmeyer labels a direct form of silencing. ${ }^{20}$ Using propaganda and physical violence, the regime threatened the lives of journalists and activists who sought to expose the truth about the wars. After Milošević, the public sphere did not transform into an arena that encouraged debate, and even today debate about the past is largely ignored. This, too, silences the public.

In this article, however, I focus more on the ways in which domestic practitioners of transitional justice enact practices that silence the public. That successive Serbian governments would hope to keep their public silent and thus avoid culpability in the wars is unsurprising. I explore the rather more well-meaning practices that may inadvertently create discursive conditions that discourage public discussion. NGOs are well positioned for this examination as, in Serbia, they are often the only domestic actors engaged directly with projects that target the public. Various Serbian governments can make no such claims, and their relationships to transitional justice are tenuous at best. Moreover, scholarship on Serbia appears relatively uncritical in relation to NGOs, whose positions mostly go 'uncontested. ${ }^{21} \mathrm{NGO}$ activists come across as speakers for the public, and much scholarship engages exclusively with them. 'The society' thus emerges as a subject constructed through this academic-practitioner dialogue.

The insights in this article are drawn from a larger, ethnographic study on narratives about the 1991-1999 wars and war crimes offered by 'ordinary' individuals who are not explicitly involved in politics or civil society activism and who can be said to form the target audience for most transitional justice initiatives in Serbia. The study, carried out between 2005 and 2007, consisted of 36 recorded semistructured interviews (as well as unrecorded interviews, conversations and ethnographic observations) with individuals of Serb ethnicity living in Belgrade. Their ages ranged 
from 18 to 82 . None of the respondents took part in the wars, but many had family members or friends who participated as conscripts or as volunteers, some of whom were killed. I collected their narratives about the wars and observed the performances that accompanied them, such as silences, crying, gestures and the spaces within which the narratives were told. In this case, I understood narrative as 'a story, and stories tell about things that have happened or are happening to people. ${ }^{22}$ The study is relatively small in terms of sample size, ${ }^{23}$ but I did not aim for generalizable trends, rather seeking to explore the range of ways in which the respondents understood and made sense of the violence and war crimes.

This article first examines the relationship between transitional justice and silence. It then discusses different approaches to silence and silencing before presenting a case study of transitional justice practice in postconflict Serbia. It elaborates how most domestic civil society projects interpret transitional justice as a truth-recovery process and base their work on 'confronting the past' as an act of silence-breaking directed at the general public. Then, the article considers how the public nature of these initiatives is in direct tension with the ways in which knowledge about war crimes and human rights abuses normally circulates amongst Serbian individuals and communities. It describes how the practice of transitional justice, which focuses on public testimony, creates a dilemma for actors unable or unwilling to speak, or be heard, ${ }^{24}$ under these discursive conditions.

\section{Transitional Justice, Truth and Silence}

Transitional justice is similar to human rights activism in its drive to reveal 'secrets of hidden violence' and inspire observers to action. ${ }^{25}$ It relies on 'the assumption that witnessing results in understanding and requires response. ${ }^{26}$ The field likewise seeks responses to violent or criminal pasts, often via truth-telling initiatives. ${ }^{27}$ It fights against the absence of elicited responses, ${ }^{28}$ but it also tries to ensure that when silence is broken, victims, observers and even perpetrators have a voice with which to speak, through mechanisms such as truth commissions. ${ }^{29}$ As suggested by Ari Gandsman, much of this is premised on the idea of the silent victim whose 'healing' can be reached through testimony. ${ }^{30}$ By combating silence, transitional justice aims to produce narratives about the past.

This fits with broader trends in peacebuilding to which transitional justice is closely linked. For instance, Gearoid Millar argues that 'centrality of truth' is located in the peacebuilding literature, where it is one of 'the dominant paradigms of postwar trauma and healing, ${ }^{31}$ and that in 'the West ... truth and knowledge are seen as inherently good and healing. ${ }^{32}$ Reflecting on Sierra Leone, Rosalind Shaw points out that the truth-telling paradigm within which truth commissions operate has emerged as 'natural' and 'universal. ${ }^{33}$ According to Simon Robins, truth is often understood to mean reconciliation. ${ }^{34}$

This discursive, 'confessional' approach ${ }^{35}$ to postconflict peace and justice can in part be attributed to the growth of what Vanessa Pupavac refers to as 'therapeutic governance,' in which postconflict experiences are 'psychologised' based on an Anglo-American interpretation of 'emotional disfunction. ${ }^{36}$ Traumatization, Pupavac argues, and a need for healing are often observed by international actors and donors, ${ }^{37}$ with assistance from local civil society and grassroots organizations. Transitional justice draws on this psychological tradition in which silence is framed as the 'failure of speech' and 'a dysfunctional absence' redeemed 'through the restoration of voice.'

Much of these arguments relates to transitional justice in its original, narrow, legalistic conception, which is often a top-down process carried out through institutions such as war crimes courts or tribunals with little regard for local dynamics. Whilst transitional justice, in practice and the literature, has broadened out from these original views to incorporate a wide variety of community initiatives, mechanisms and local initiatives, ${ }^{39}$ it still carries a strong focus on silence-breaking activities. Moreover, the critique of this approach expressed by scholars working in nonEuropean contexts has not been applied to Serbia, where transitional justice continues to be driven by silence breaking. ${ }^{40}$

In seeking public deliberation on the past, transitional justice actors prioritize immediately audible responses (testimonies, narrative responses) without taking into account that responses to past violence are not always spoken. ${ }^{41}$ Whilst relying on narrative and discourse, transitional justice initiatives rarely consider the working 
mechanisms of speech and problems faced by individuals when speaking about violence. ${ }^{42}$ Importantly, much transitional justice practice is unreflexive about the kinds of discursive conditions its formal and informal initiatives create. $^{43}$

\section{Approaches to Silence}

Silence is frequently conceptualized as an absence of speech, ${ }^{44}$ and thus often understood in negative terms, ${ }^{45}$ especially when it occurs under repressive regimes. ${ }^{46}$ For instance, both Eviatar Zerubavel and Stanley Cohen equate silence with ignorance and denial, and even conspiracy, where 'a group of people tacitly agree to outwardly ignore something of which they are all personally aware. ${ }^{47}$

I follow a more critical and exploratory approach to silence, where silences are understood as integral parts of speech. ${ }^{48}$ Whilst silences, individual or collective, can indicate a forgetting of an incident or an event, ${ }^{49}$ this is not the only interpretation. As Carol Kidron points out, silences, particularly those surrounding difficult or violent pasts, can be sites of communication. ${ }^{50}$ Indeed, silence can be understood as 'the ultimate example of acknowledgement and remembrance. $^{, 51}$

In her study of Holocaust survivor families, Kidron suggests that the past can be remembered silently and remembrance embodied in everyday objects and practices. ${ }^{52}$ Furthermore, memory and acknowledgement of violence can also be performed. Pilar Riaño-Alcalá and Erin Baines suggest that memory is not only composed of 'evidentiary documents' but also contained in 'performative elements of testimony' that include silences and pauses. Thus, 'the archive' can be 'inscribed on the bodies of tellers and listeners. ${ }^{53}$ As Kidron points out, however, this view of silence as a 'medium of ... transmission of knowledge' is neglected in the focus on 'logocentric' aspects of silence. ${ }^{54}$ But, as a number of scholars suggest, the problematization of silence tends to be a Eurocentric concern, ${ }^{55}$ as there are practices that do not conform to the 'western, confessional model of healing. ${ }^{56}$ These elements are rarely captured by the transitional justice mechanisms deployed in Serbia.

Importantly, some silences are the result of silencing, ${ }^{57}$ which may be due to institutional biases, oversights or exclusions, both accidental and intentional, ${ }^{58}$ or to self-imposed censorship or a lack of attention. ${ }^{59}$ As Thiesmeyer writes, the creation of particular narratives can be shaped by individuals and institutions with (in)formal means of power that determine which voices can or should be excluded. ${ }^{60}$ For instance, Kirk Simpson explores how Northern Ireland unionists feel that the stories of their victims have 'remained untold, silenced by their political opponents. ${ }^{61}$

Silences are complex sites of intersecting tensions. Individuals and communities may be trapped in what Lene Hansen calls 'silent dilemmas,' where they may feel the need to remain silent as speaking may endanger them. ${ }^{62}$ Silences may appear to be a 'choice,' Hansen argues, but they are more likely to be imposed by structures, practices, traditions and discourses, ${ }^{63}$ as well as poverty and social exclusion. ${ }^{64}$ Reliance on speech to convey problems is a notion that presupposes that speaking is possible ${ }^{65}$ and 'desirable. ${ }^{66}$

To explore dynamics of silence in Serbia, I draw on Thiesmeyer's 'theory of silencing,' based on Foucault's regulatory discourse, which 'constructs and edits ... knowledge. ${ }^{67}$ Thiesmeyer's theory of silencing is concerned with 'disguised' forms of silencing in addition to more overt forms such as those resulting from totalitarian repression. ${ }^{68}$ Importantly, she notes that 'enlightened forms of silencing' that 'supply other language in the place of the silenced material' offer a 'simulacrum of freedom of expression or of choice among discursive alternatives. ${ }^{69}$ They also produce 'those who cannot speak' ${ }^{70}$ and assumptions that 'since they are not being heard from, they are therefore not trying to say anything. ${ }^{71}$

I follow Thiesmeyer's investigations into how identification 'of groups and discourses about (not by) [certain individuals and communities] arise, and how such discourses are used to construct these entities as silencable. ${ }^{72}$ This is similar to the perception of 'the Serbian public' as described by transitional justice initiatives. 


\section{Transitional Justice in Serbia}

Successive Serbian governments have been unsympathetic to transitional justice and cooperated reluctantly with the ICTY. Lack of government involvement has stifled debates about the past and allowed for the public sphere to be monopolized by a large number of revisionist pundits, religious leaders and far-right groups that periodically engage in war crimes denial.

Since the early 1990s, civil society actors have attempted to initiate anti-war and anti-nationalist campaigns, ${ }^{73}$ with some, such as the Humanitarian Law Centre, focusing on transitional justice. Domestic transitional justice discourse and practice have been dominated by NGOs as the most visible civil society actors, including Helsinki Committee for Human Rights in Belgrade, Belgrade Centre for Human Rights, Youth Initiative for Human Rights and Women in Black. As Jasna Dragović-Soso notes, their approach to the past has been fragmented, ${ }^{74}$ but much of their work revolves around silence-breaking activities, including publishing, public speaking, campaigning or commemorating massacres and visiting genocide sites. Many campaigns are aimed at the Serbian public. This has led to the development of the discourse on 'confronting the past, ${ }^{, 75}$ which includes 'broad acknowledgement' that Serbs and their leaders committed atrocities in the $1990 \mathrm{~s} .{ }^{76}$ Recently, a coalition of activists has commenced a campaign for a truth commission in the region, ${ }^{77}$ arguing that public advocacy is crucial to establishing truth about the past. ${ }^{78}$

In Serbia, a significant 'academic-practitioner synergy' has emerged in transitional justice work, which is a common trend in the field. ${ }^{79}$ For instance, scholars work with domestic NGOs in collaborative projects or ask NGOs' opinions about Serbian society's engagement with transitional justice. ${ }^{80}$ This is echoed by Zinaida Miller in the suggestion that that 'there is a tendency of scholars or ex-commissioners to become consultants to, rather than fully external critics of, the [transitional justice] enterprise. ${ }^{81}$ Thus, experts speak to other experts (activists) about 'the public' and activists' voices become amplified whilst obscuring voices of 'the public,' the subject of that discourse. This is problematic as the Serbian public tends to hold negative views of NGOs and criticizes their lack of engagement with the domestic audience. ${ }^{82}$

Within transitional justice in general and Serbia in particular NGOs are not often understood as 'actors that exercise power. ${ }^{, 83}$ This results in often uncontested representations of the 'silent public' they construct. The priority given to 'alternative voices, ${ }^{, 84} \mathrm{NGOs}$ and experts, and the lack of visibility of the public in narratives about itself, has resulted in the silencing of a vast range of experience and knowledge about the violent past that individuals embody, circulate and believe. ${ }^{85}$

\section{The 'Silent Public'}

Several overlapping layers of silence and silencing exist in Serbia. The Milošević regime silenced the public, opposition, media and activists in a very direct and repressive way. ${ }^{86}$ Post-Milošević governments, meanwhile, have been complicit in an insidious form of silencing by not creating conditions under which speaking about the past is welcomed. ${ }^{87}$

Silencing in Serbia also occurs through omission and neglect. ${ }^{88}$ Although it appears that transitional justice practice does anything but ignore the public (given its focus on engaging the public in debates), the public in many campaigns and statements exists primarily as a subject 'constituted ${ }^{\prime 29}$ through the academic-practitioner dialogue. The public is at once visible and invisible, constantly referred to or implied in criticisms of Serbia's failure to confront the past and yet with virtually no voice of its own. ${ }^{90}$ When the public 'speaks,' it does so through surveys (which flatten the diversity of experience and allow the public to speak only through pre-prepared statements) and practitioners, and is not in control of its own narrative. Instead, 'the public' is assigned a subjectivity, 'the felt interior experience of [a] person that includes his or her positions in a field of relational power. ${ }^{91}$ This silences the public further, as surveys do not give individuals the opportunity to voice their own stories in their own terms. Wartime realities for most respondents were much more complex than, for instance, surveys would be able to capture.

One particularly alienating, and thus silencing, practice is the misunderstanding of how stories of violence and war crimes are remembered and narrated. They are not always immediately visible but are embedded deep within social 
interactions, exchanges and silent acknowledgement. ${ }^{92}$ Many of these stories and their telling are governed by implicit social rules. For instance, in social gatherings, such stories may be hinted at but their telling is quickly thwarted. Discussions of violence are particularly avoided around children. I witnessed, for instance, occasions where teenagers asked their parents to explain a television news item we had just watched featuring a war criminal or the story of a massacre and the parents refused to do so. This dynamic occurred in all discussions of death and violence (such as suicide), not war crimes and political violence alone. Despite this, wartime stories do circulate, and it is often grown-up children who are their 'keepers.' This group, in its twenties, tells stories of close relatives who fought in the wars, cousins killed in the conflicts, friends who committed suicide after returning from Kosovo or neighbours who volunteered for paramilitary units and 'never came back' - stories their parents avoid. But, knowledge about the violent past circulates, and the stories' often ambiguous details embody knowledge of atrocities. The possibility that a family member may have been implicated in war crimes was never explicitly denied during my research.

These elusive stories are situated in an everyday world, closely guarded against intrusive and violent topics. Reluctance to talk about violence was evident when my respondents discussed a Youth Initiative for Human Rights campaign commemorating the 10th anniversary of the Srebrenica genocide. ${ }^{93}$ The campaign included posters and billboards urging the public 'To See, To Know, To Remember.' One image appeared to be a child's decomposing hand. A respondent recalled his confusion regarding the campaign; he was at a loss as to what the initiative 'wanted us to do.' He did not talk about his impressions to anyone, and mentioning them to me was, he admitted, the first time he had talked about this at all. ${ }^{94}$

Such campaigns do not resonate with individuals whose engagement with war crimes is one not of public discussion but of silent knowing. ${ }^{95}$ There are situations in which, as both Hansen and Claire Wilkinson point out, it is not always possible or desirable to speak or protest. ${ }^{96}$ Acknowledgements of crimes committed against others can be performed without being explicitly verbalized. ${ }^{97}$ One respondent, for instance, began crying as she recalled news coverage of the start of the war in Croatia. ${ }^{98} \mathrm{~A}$ male respondent had an archive of press clippings that detailed several Serb-committed atrocities. ${ }^{99}$ A younger respondent, a teenager at the start of the wars, attempted to come to terms with them by reading as much as possible and 'trying to imagine' what it must have been like to live under the siege of Sarajevo. He travelled to Bosnia and spoke to people there about the war. ${ }^{100} \mathrm{~A}$ female respondent spoke frequently of a Bosniak friend who survived the Sarajevo siege. She mentioned the friend's coping mechanisms and acknowledged implicitly what she must have suffered (referring to the friend's experience as 'horrifying' and 'tragic'), yet never spoke directly of it. ${ }^{101}$ These silent, personal reflections demonstrate some kind of engagement with past violence, yet one not articulated so that it is readily 'heard' and understood by transitional justice practitioners. Practitioners seek public engagement and explicit apologies, not recognizing the fragmented way individuals cope with and talk about violence or establishing mechanisms for their inclusion.

\section{The Unknowledgeable Public}

Another practice that silences the public is the disconnect between what NGO campaigns claim the public knows and does not know about the past and what individuals know but do not communicate. The Serbian public is frequently constructed as needing to be (re)educated. For instance, the Belgrade Centre for Human Rights ran a project on 'Crimes and Punishment in the Minds of People: The Internalization of the ICTY Legacy.' ${ }^{102}$ The project 'focuses on improvement of knowledge' and 'tackling a number of stereotypes and misconceptions among general public' regarding the ICTY and war crimes. In 2010, the centre ran the 'News from the Past: Historical Illusions, Misconceptions about the Past and Their Social and Political Effects' project, which targeted 'citizens' and whose aim was 'not to study the attitudes of the public ... and wonder about their origin and seek explanation for their existence.' Explicit about its aims at reeducation, the centre wished to influence and change

"the attitudes of those who are able to command the attention of the majority of citizens and can act convincingly to persuade them to think differently and to revise some of their deeply held perceptions of historical events. ${ }^{103 "}$ 
In general, it is made clear that one of the things that has to change is "the Serbs" perception of their own community as victims. ${ }^{104}$ However, such projects assume that 'the public' is misinformed and uncritically subscribes to the 'Serbs as victims' view. This view constructs the public as a subject that has to admit publicly its ignorance and engage with transitional justice initiatives on those terms. This contributes to the 'silent dilemma, ${ }^{105}$ as individuals may be reluctant to engage on this basis, preferring to keep silent in order not to be labeled 'ignorant.'

Participating in transitional justice initiatives means that one must speak within set boundaries. Often these boundaries oscillate around the underlying notion of 'confronting the past,' the debate that centres on 'the Serbs" acknowledgement of atrocities committed against 'ethnic others.' Generally, however, narratives about the past contain this and more. Most individuals in Serbia have some connection to the wars in the former Yugoslavia, as many lost friends or relatives in the wars or had sons drafted to fight, some of whom were subsequently killed. Among the respondents, such stories were embedded in and part of narratives that acknowledged brutal crimes committed by Serb forces. These experiences were not divorced from the regret they expressed about the loss of ethnic others' lives or the horror they felt at knowing that Serbs committed war crimes. A resonant interpretation of transitional justice by the respondents in this study was that these stories are rarely heard because the conditions set for speaking publicly are usually centred on the singular issue of admitting that 'Serbs' committed war crimes.

Interviews with respondents on issues relating to war crimes revealed not that they were, as Simpson puts it, 'against truth recovery in some form,' but rather that they felt 'their stories lack an audience. ${ }^{106}$ For instance, one of my respondents, a male student in his twenties and a supporter of transitional justice, could not reconcile his experience of the wars with what he perceived to be a discussion focused on Serbian guilt. He spoke of how different his experience of the 1990s, in a small Serbian town, was compared to how this is often represented. Here, he presents stories of personal tragedies and resistance to the wars:

"There were ... 48 men in [the town], all reservists, who threw their weapons down once they were called up and refused to go to war ... because they had people coming back [from the war] before them and bringing home bombs, guns, ammunition ... One of my friends went to the army when he was 18 , and he was in [the war in] Kosovo. When he returned, he committed suicide. There were a lot of bad things like that. ${ }^{107 "}$

Similar sentiments were expressed by other respondents, who felt not only disenfranchised from the decisionmaking mechanisms that took Serbia to war but also unable to do anything about the conflicts. An older male respondent noted,

"I remember that no one asked me if we should go to war or not ... I keep repeating that, because no one asked me ... I couldn't comprehend that there would be someone crazy enough who would take the country to war. ${ }^{108 "}$

The collected narratives, as illustrated briefly above, hide numerous stories of resistance, particularly opposition to the wars and Milošević. Whereas some scholars argue that Serbian citizens can be deemed 'responsible for atrocities of their state because they provided a permissive social and political environment for the atrocities to occur and did not do enough to prevent them, ${ }^{109}$ the reality is far more complex. Acts of resistance against the regime were not always visible, nor was it always possible to make them public. Respondents engaged in 'everyday resistance ${ }^{\prime 110}$ and subtle forms of opposition, with many thus refusing to engage or believe in Milošević propaganda. Less 'everyday' but likewise 'invisible' resistance came in the form of acts directed at opposing the regime's nationalist policies. For instance, one female respondent helped hide her son's friend who was evading the draft for the war in Kosovo. ${ }^{111}$ Several respondents also had children or close relatives who emigrated from Serbia in the 1990s partly in response to Milošević-era politics. As Wilkinson highlights, migration as protest is just one of the 'silent' forms of opposition employed by those who are unable to 'speak.'112 These 'protests' against war and nationalist politics were enacted within the space of the home, the only sphere respondents felt they could control, and which many guard against unwelcome intrusions such as depictions of violence and death. 
Respondents also circumvented the Milošević regime's silencing and repression of atrocities by learning about the scale of the fighting from refugees, conscripts and volunteer fighters. These stories often diverged from the propaganda that Serbs were engaging in 'self-defence.' According to a young respondent whose father, a Bosnian Serb, made frequent trips to Bosnia during the war,

"I would say it was pretty horrific ... In those parts where he is from, for example, Serbs were selling bullets to the Muslims ... He said, 'We've sold out' ... He can't stand this Ratko Mladić who bombarded Sarajevo from a hill. He told me all kinds of things that happened there ... He said what Serbs did to the Muslims and what Muslims did to the Serbs ... What affected me was when he told me that these people that we knew, that they were slaughtered. ${ }^{113}$

The respondents thus actively resisted the silencing of the Milošević era by circulating stories and 'storing' knowledge about atrocities through social interactions or 'silent acknowledgement., ${ }^{114}$ Rather than participating in a tacit agreement to keep silent and deny crimes (Zerubavel's 'conspiracy of silence'), ${ }^{115}$ many respondents indicated that they did not talk about these events because they were, in the words of one respondent, 'too horrible.' Hence, silence was enacted not because respondents did not know about the crimes or denied them but because they knew and found it difficult to speak about them. ${ }^{116} \mathrm{~A}$ female respondent who learned about some atrocities committed by Serbs in Sarajevo from Bosnian Serb refugees in her neighbourhood said,

"There was so much insanity there, I don't know if insanity is the right word. I don't know, really. You can't even say they are bestial crimes, because even beasts wouldn't do the kinds of things they did to each other, everyone. That's something that stays with you, and within all that you don't see a speck of reason, a speck of humanity. No. There is nothing human there, it wasn't, it was killing, but also torture, torturing someone until he really dies ... I just don't have the words. ${ }^{117 "}$

This extract is one of many examples of respondents admitting to struggling to make sense of the wars and violence, whilst also struggling to find the words with which to articulate their meaning. ${ }^{118}$ As Elaine Scarry explains, euphemisms and metaphors are used in discussions of violence that frequently result in omissions. ${ }^{119}$ Violence, according to Michael Taussig, has the effect of destroying language. ${ }^{120}$ Furthermore, as Valentine Daniel points out, individuals show a marked inability to express violent events in 'known' terms, which suggests the 'unshareability' of pain. ${ }^{121}$ In transitional justice, however, there is frequently an expectation that victims, perpetrators and witnesses will communicate verbally about events that are frequently labelled 'unspeakable. ${ }^{122}$ The inability to speak about violence - through lack of appropriate vocabulary or capability to conceptualize and verbalize violent events creates yet another layer of silence.

\section{The Collective Experience and the Ethnic Subject}

Another act of silencing occurs through the implicit collectivization of the wartime experience and confronting the past. For instance, the public is frequently, interchangeably or inconsistently referred to as 'the Serbs' or 'Serbia.' This results in 'slippages of meaning,' which, as Lila Abu-Lughod points out, create 'hyphenated entities' and obscure complex relationships. ${ }^{123}$ This is one of the reasons why the public is invisible in transitional justice debates: the Serbs-Serbia-Serbian society or 'the public' exists primarily as an imagined audience, constructed through expert narrative. Further, this narrative implicitly collectivizes, homogenizes and flattens the society and its experience of the past, disregarding complex realities, such as the acts of resistance described above. As Johanna Mannergren Selimović finds in a recent study on Bosnia, local- and individual-level narratives of wartime violence often contest various collective interpretations. ${ }^{124}$

Moreover, 'the public' is explicitly constructed as an ethnic subject ('the Serbs'), without regard as to whether this assignation of identity has any resonance. ${ }^{125}$ As Cilian McGrattan argues, this approach silences nonethnic experiences of conflict, ${ }^{126}$ and the past. Much of the debate on how Serbia should come to terms with the past has revolved around the question of whether transitional justice initiatives should be 'de-ethnicised. ${ }^{127}$ Specifically, the debate at one point focused on whether all victims of past wars should be acknowledged and included in transitional 
justice initiatives in Serbia. A leading activist, Sonja Biserko, however, has pointed out that this should not be the case as Serbs/Serbia committed the most crimes. ${ }^{128}$ Indeed, as Stef Jansen argues, people died because of ethnic labels, ${ }^{129}$ so this category should not be dismissed so easily. However, not all 'Serbs' supported ethnonationalist politics or understood war (or themselves) as 'ethnic' subjects, and hence many find it difficult to engage in debates about the past in ethnic terms. Among my respondents, victims of the wars were often identified and mourned as 'poor people' or 'ordinary people,' as suggested by the two extracts below from a male and a female respondent, both in their 60s:

"People against people, one people destroying another. Serbs destroying Muslims, Muslims destroying Serbs. A civil war. If it wasn't for those four [leaders] there would have never been a war. I would have never gone to fight against a Muslim, why would I when I worked with them ... like we were brothers? No one asked you what you are ... We were not bothered. ${ }^{130 "}$

"I feel so sad about it. I read what happened in Slavonia [a Croatian region caught up in the 1991-1995 war], what kinds of brutalities they carried out ... That is horrible! And all the destruction of houses. A house-gas, they close the windows and shoot a bullet with flames or maybe something else but the house burns down and everything in the house. Horror! ... But what makes me the saddest is human victims. You can't make up for someone's life ... I'm really sad it all happened, that a brother could turn on his brother. Everyone used to live together, Serbs in Bosnia with Muslims and Croats, and suddenly, they took their guns out and started shooting each other. And those mass graves, and those murders, they really unsettled me. ${ }^{131 "}$

These respondents offer a rejection of ethnic, Serb-centric positioning and are far from replicating or assenting to Milošević-era ideology. Instead, the rejection of ethnic subjectivity is related to the nonethnic identifications that respondents often emphasized. For instance, older respondents spoke of their past compatriots across the former Yugoslavia in familial rather than ethnic terms. They rarely said 'Croats' or 'Muslims,' instead saying 'brothers,' 'family' and 'neighbours.' Curiously, perpetrators of atrocities were likewise rarely identified ethnically. Whilst respondents broadly accepted that individuals from their community and country committed war crimes, they often sought to identify perpetrators as caricatured, extreme and marginal examples from each community.

Many transitional justice campaigns in Serbia focus on exposing Serb crimes against ethnic others and obtaining Serb acknowledgement and apology. Whilst this should certainly be a part of transitional justice projects, as McGrattan suggests, the focus on ethnicity oversimplifies and disregards the complex identities and experiences of violence. ${ }^{132}$ Respondents in this study demonstrated that they understand the wars in terms much broader than those used by transitional justice practitioners. Further, ethnicity as 'the public's' primary mode of interpreting the conflicts is often simply assumed. As McGrattan points out, in certain cases, ethnic framing within transitional justice is partly due to a preference in elite politicians' and academic narratives that disregards 'marginal experiences of conflict based on gender, class and locale. ${ }^{133}$ That this 'disregard' occurs in some postconflict contexts sits sharply against a growing literature and critical reflections on 'marginal,' nonethnic or gendered experiences of violence and war. ${ }^{134}$ But, where transitional justice mechanisms end up ignoring these dimensions, McGrattan argues, 'the burden of reconciliation is imposed on the vast majority of individuals who rejected violence ${ }^{135}$ - individuals who did not support conflict or identify with the 'ethnic' or collective experience, and who remain alienated from transitional justice initiatives.

\section{The 'Silent Dilemma'}

The final question, thus, is whether sections of 'the public' in Serbia do know about the past, acknowledge the crimes committed, feel apologetic, reject nationalist ideologies and did not agree with wartime politics. If they do, why are they never 'heard'? This is the result of two dynamics: first, what and how they communicate about the past is carefully mediated ${ }^{136}$ - to the point where silence is also 'reactive ... to the intervention of experts ${ }^{137}$ - and, second, the social and cultural capital, opportunity and enthusiasm for being involved with transitional justice initiatives are lacking. 
NGOs, currently the key actors behind attempts to 'break the silence' of the public, set up their campaigns in a way that it makes it difficult for the public to be heard. The initiatives are either one-directional (as with the abovementioned reeducation project) or require material or physical engagement, such as presence at talks and panels. NGOs usually push for public visibility while individuals cope with knowledge and acknowledgement privately, and often silently, in order to 'control' their knowledge and feelings. ${ }^{138} \mathrm{NGOs}$ also often misunderstand or overlook the material, financial and social location of their audience. As I illustrated at the beginning of this article, individuals require free time as well as cultural and social capital in order to take part in NGO initiatives. As Denisa Kostovicova points out, low levels of social capital and trust have led to generally low participation in civil society across postsocialist Eastern Europe. ${ }^{139}$ The respondents I interviewed complained that NGOs operate in ways that are unfamiliar to them and in contexts in which they would feel alienated. For instance, one respondent believed that if he attended a talk organized by NGOs, he would not know what to say and would feel 'patronized.' ${ }^{140}$ A young respondent complained that as NGO workers earn more than most 'ordinary people,' she would feel uncomfortable at gatherings of well-dressed, confident activists. ${ }^{141}$ This might sound trivial, but it demonstrates that alienation from public sphere discussions can occur in many forms that are not accounted for when the 'silent public' is criticized for its lack of empathy and participation.

In Serbia, the pursuit of public narratives and engagement with the past has resulted in silenced voices, in individuals who find it impossible or difficult to make themselves visible and audible and so to be seen and heard to be participating in transitional justice initiatives. They are 'voices twice silenced, ${ }^{142}$ first, by the conditions of engagement set forth by transitional justice initiatives and, second, by their own perception that their stories are unwanted. Individual actors are then stuck between two equally undesirable options: engage with transitional justice initiatives (i.e., speak publicly about the past) or remain silent.

Overall, 'the public' - at least the respondents presented here - is caught up in a 'silent dilemma. ${ }^{143}$ It is unable to speak and fearful that attempts at speaking will result in unwelcome attention, such as being further constructed as a problematic audience. Silence is thus used as Hastings Donnan and Simpson suggest, strategically, in order to manage feelings. ${ }^{144}$ The prioritization of public engagement and silence breaking has created a dominant discourse on the past and established what kinds of positions must be held towards it. This discourse implies not only that speakers cannot deny the past but also that they should not remain silent and that they should engage in public acts of acknowledgement and apology on very particular, usually ethnic 'Serb' terms. This is a Foucauldian regulatory discourse that sets the parameters for what can and cannot be said. As silencing, it 'designates the dominant potential for retaliation against the autonomous political agency of rebel speech. ${ }^{145}$

'Rebel speech' ${ }^{146}$ includes everything that falls outside the parameters of transitional justice discourse: explicit apology, public discussion, a broken silence. According to Thiesmeyer, language can be used as a silencing tool as certain forms of language can be given priority and legitimacy over others. ${ }^{147}$ Thus, 'the public' whose engagement is called upon to battle silence about the past is included in civil society debates only if it is heard saying the right thing.

\section{Conclusions}

Transitional justice scholarship is continually widening, but not enough attention is paid to its relationships with silence, language, narrative and communication of violence. If transitional justice is to capture a range of complexities engendered by postconflict societies and individuals, bringing in theories of silencing and reflecting on the use of language could help expose issues that are not immediately obvious or visible. Some of these issues include the ways in which audiences, instead of being participants in transitional justice debates, can become 'trapped' observers or 'silent subjects.' Transitional justice practice is rarely reflexive about the kinds of discursive conditions and opportunities for participation it creates. It frequently assumes that speaking and taking part ought to take place without much difficulty. However, that large numbers of people do not take part can be understood by considering the 'silent dilemmas' ${ }^{148}$ created within transitional justice practice and asking who cannot speak, and why. 
Specifically, as the example of Serbia shows, asking those questions in order to understand silence can be obscured by the normative push towards reconciliation. Furthermore, the same logic disables transitional justice actors from asking questions about their complicity in creating silences. By decoupling 'silence' from 'denial' and engaging in deeper empirical research with target audiences, transitional justice practice and scholarship can start to expose some of the mechanisms that exclude, rather than include, participants and to uncover the complexities inherent within silences.

\section{Footnotes}

1 Research for this article was initially funded by the Economic and Social Research Council.

2 Slavenka Drakulić, 'First Justice. Next, Truth. Only Then Is Reconciliation Possible,' Guardian, 23 July 2008.

3 Diane F. Orentlicher, Shrinking the Space for Denial: The Impact of the ICTY in Serbia (New York: Open Society Justice Initiative, 2008 ), 85.

4 Marijana Toma, 'Suočavanje sa prošlošću,' Al Jazeera Balkans, 26 April 2012. This and all translations from the Serbian by author. Interpretative denial is discussed in Stanley Cohen, States of Denial: Knowing about Atrocities and Suffering (Cambridge: Polity Press, 2001).

5 Janja Beč, 'Od hate speech do hate silence: Banalna ravnodušnost,' in Srebrenica od poricanja do priznanja (Belgrade: Helsinki Committee for Human Rights, 2005), 14.

6 Carol A. Kidron, 'Toward an Ethnography of Silence: The Lived Presence of the Past in the Everyday Life of Holocaust Trauma Survivors and Their Descendants in Israel,' Current Anthropology 50(1) (2009): 5-27.

7 Jessica Greenberg, "There's Nothing Anyone Can Do About It": Participation, Apathy, and "Successful" Democratic Transition in Postsocialist Serbia,' Slavic Review 69(1) (2011): 42.

8 Personal interview, R.M., Belgrade, Serbia, 24 May 2006. Initials refer to pseudonyms.

9 Lynn Janet Thiesmeyer, 'Introduction: Silencing in Discourse,' in Discourse and Silencing: Representation and the Language of Displacement, ed. Lynn Janet Thiesmeyer (Philadelphia, PA: John Benjamin Publishing, 2003).

10 Greenberg, supra $\mathrm{n} 7$ at 42.

11 Claire Wilkinson, 'The Copenhagen School on Tour in Kyrgyzstan: Is Securitization Theory Useable Outside Europe?' Security Dialogue 38 (1) (2007): 5-25.

12 Thiesmeyer, supra $\mathrm{n} 9$.

13 Wilkinson, supra $\mathrm{n} 11$.

14 See, for example, Harry G. West, 'Voices Twice Silenced: Betrayal and Mourning at Colonialism's End in Mozambique,' Anthropological Theory 3(3) (2003): 343-365.

15 Notable exceptions include Pilar Riaño-Alcalá and Erin Baines, 'The Archive in the Witness: Documentation in Settings of Chronic Insecurity,' International Journal of Transitional Justice 5(3) (2011): 412-433; Marita Eastmond and Johanna Mannergren Selimović, 'Silence as Possibility in Postwar Everyday Life,' International Journal of Transitional Justice 6(3) (2012): 502-524.

16 Gurminder K. Bhambra and Robbie Shilliam, 'Silence and Human Rights,' in Silencing Human Rights: Critical Engagements with a Contested Project, ed. Gurminder K. Bhambra and Robbie Shilliam (Basingstoke: Palgrave Macmillan, 2009$), 1$.

17 Ibid.

18 Ibid. Also see, Zinaida Miller, 'Effects of Invisibility: In Search of the "Economic" in Transitional Justice,' International Journal of Transitional Justice 2(3) (2008): 266-291.

19 Bhambra and Shilliam, supra n 16; Miller, supra n 18.

20 Bhambra and Shilliam, supra n 16.

21 Theodora Vetta, “'Democracy Building” in Serbia: The NGO Effect,' Southeastern Europe 33(1) (2009): $26-47$.

22 Arthur Asa Berger, Narratives in Popular Culture, Media and Everyday Life (Thousand Oaks, CA: SAGE, 1997$), 4$. 
23 The study was limited by deadlines and budgetary concerns as it was part of my PhD research.

24 Wilkinson, supra n 11.

25 Winifred Tate, Counting the Dead: The Culture and Politics of Human Rights Activism in Colombia (Berkeley, CA: University of California Press, 2007), 165.

26 Ibid., 165.

27 John Borneman, 'Why Reconciliation? A Response to Critics,' Public Culture 15(1) (2003): 199-208.

28 See, Bhambra and Shilliam, supra $\mathrm{n} 16$.

29 See, Miller, supra $\mathrm{n} 18$.

30 Ari Gandsman, 'Testimonies of Trauma, Human Rights, and the Reproduction of Conventional Knowledge' (paper presented at the 'Beyond Testimony and Trauma: Oral History in the Aftermath of Mass Violence' conference, Montreal, Canada, 24 March 2012).

31 Geariod Millar, 'Assessing Local Experiences of Truth-Telling in Sierra Leone: Getting to "Why" Through a Qualitative Case Study Analysis,' International Journal of Transitional Justice 4(3) (2010): 481.

32 Gearoid Millar, 'Between Western Theory and Local Practice: Cultural Impediments to Truth-Telling in Sierra Leone,' Conflict Resolution Quarterly 29(2) (2012): 192.

33 Rosalind Shaw, 'Memory Frictions: Localizing the Truth and Reconciliation Commission in Sierra Leone,' International Journal of Transitional Justice 1(2) (2007): 183.

34 Simon Robins, 'Challenging the Therapeutic Ethic: A Victim-Centred Evaluation of Transitional Justice Process in Timor-Leste,' International Journal of Transitional Justice 6(1) (2012): 83-105.

35 West, supra n 14.

36 Vanessa Pupavac, 'International Therapeutic Peace and Justice in Bosnia,' Social and Legal Studies 13(3) (2004): 377.

37 Ibid.

38 Kidron, supra $\mathrm{n} 6$ at 7.

39 See, Kieran McEvoy and Lorna McGregor, eds., Transitional Justice from Below: Grassroots Activism and the Struggle for Change (Oxford: Hart Publishing, 2008).

40 Shaw, supra n 33; West, supra n 14.

41 For instance, West, supra n 14.

42 See, Valentine E. Daniel, Charred Lullabies: Chapters in an Anthropography of Violence (Princeton, NJ: Princeton University Press, 1996).

43 See, Michelle Staggs Kelsall and Shanee Stepakoff, “'When We Wanted to Talk About Rape”: Silencing Sexual Violence at the Special Court for Sierra Leone,' International Journal of Transitional Justice 1(3) (2007): 355-374.

44 Kidron, supra $\mathrm{n} 6$.

45 See, Bhambra and Shilliam, supra n 16.

46 Thiesmeyer, supra $\mathrm{n} 9$.

47 Eviatar Zerubavel, The Elephant in the Room: Silence and Denial in Everyday Life (New York: Oxford University Press, 2006), 3. See also, Cohen, supra $\mathrm{n} 4$.

48 Wendy Brown, 'Freedom's Silence,' in Censorship and Silencing: Practices of Cultural Regulation, ed. Robert C. Post (Los Angeles: Getty Research Institution, 1998).

49 Vered Vinitzky-Seroussi and Chana Teeger, 'Unpacking the Unspoken: Silence in Collective Memory and Forgetting,' Social Forces 88(3) (2010): 1103-1122; Kathy Charmaz, 'Stories and Silences: Disclosures and Self in Chronic Illness,' Qualitative Inquiry 8(3) (2002): $302-328$. 
50 Kidron, supra $\mathrm{n} 6$.

51 Vinitzky-Seroussi and Teeger, supra n 49 at 1108.

52 Kidron, supra $\mathrm{n} 6$.

53 Riaño-Alcalá and Baines, supra n 15 at 413.

54 Ibid., 7.

55 Charmaz, supra $\mathrm{n} 49$.

56 West, supra n 14 at 356.

57 Bhambra and Shilliam, supra $\mathrm{n} 16$.

58 Thiesmeyer, supra n 9; Miller, supra n 18; Staggs Kelsall and Stepakoff, supra n 43; Hastings Donnan and Kirk Simpson, 'Silence and Violence among Northern Ireland Border Protestants,' Ethnos 72(1) (2007): 5-28.

59 Thiesmeyer, supra $\mathrm{n} 9$.

60 lbid.

61 Kirk Simpson, 'Untold Stories: Unionist Remembrance of Political Violence and Suffering in Northern Ireland,' British Politics 3(4) (2008): 465.

62 Lene Hansen, 'The Little Mermaid's Silent Security Dilemma and the Absence of Gender in the Copenhagen School,' Millennium: Journal of International Studies 29(2) (2000): 285-306.

63 Ibid.

64 Wilkinson, supra $\mathrm{n} 11$ at 13.

65 Hansen, supra $n 62$.

66 Wilkinson, supra n 11.

67 Thiesmeyer, supra $n 9$ at 8-9.

$68 \mathrm{lbid}$.

69 Ibid., 3.

70 Ibid., 24.

71 lbid., 10-11.

72 Ibid., 10.

73 On Serbian civil society, see, for example, Denisa Kostovicova, 'Civil Society and Post-Communist Democratization: Facing a Double Challenge in Post-Milošević Serbia,' Journal of Civil Society 2(1) (2006): 21-37.

74 Jasna Dragović-Soso, 'Collective Responsibility, International Justice and Public Reckoning with the Recent Past: Reflections on a Debate in Serbia,' in The Milošević Trial: An Autopsy, ed. Timothy Waters (Oxford: Oxford University Press, forthcoming).

75 See also, Marianne Yerkes, 'Facing the Violent Past: Discussions with Serbia's Youth,' Nationalities Papers 32(4) (2004): 921-938.

76 Orentlicher, supra n 3.

77 RECOM Initiative, http://www.zarekom.org.

78 'The Team of Regional Advocates Discuss Political Support,' RECOM Initiative Voice 4 (2012), 3.

79 Gandsman, supra n 30; Miller, supra n 18. 
80 See, Denisa Kostovicova, ed., The European Union and Transitional Justice: From Retributive to Restorative Justice in the Western Balkans (Belgrade: Humanitarian Law Centre, 2007); Orli Fridman, “It Was like Fighting a War with Our Own People": Anti-War Activism in Serbia during the 1990s,' Nationalities Papers 39(4) (2011): 507-522; Orentlicher, supra n 3.

81 Miller, supra $\mathrm{n} 18$ at 290.

82 Åse B. Grødeland, "'They Have Achieved a Lot Because We Have Paid Them to Do a Lot": NGO and International Donor Perceptions of Each Other in Bosnia and Herzegovina, Macedonia and Serbia,' Global Society 24(2) (2010): 171-199.

83 Michael Barnett and Martha Finnemore, 'The Power of Liberal International Organizations,' in Power in Global Governance, ed. Raymond Duvall and Michael Barnett (Cambridge: Cambridge University Press, 2005). The authors refer here to international organizations, which I extend to NGOs.

84 Fridman, supra $\mathrm{n} 80$ at 509.

85 Veena Das and Arthur Kleinman, 'Introduction,' in Remaking a World: Violence, Social Suffering and Recovery, ed. Veena Das, Arthur Kleinman, Mamphela Ramphele and Pamela Reynolds (Berkeley, CA: University of California Press, 2001).

86 See, Thiesmeyer, supra $n 9$.

87 Ibid.

88 Ibid.

89 Leah Bassel, 'Silencing to Protect: The Debate over Women's Rights in France and Canada,' in Silencing Human Rights: Critical Engagements with a Contested Project, ed. Gurminder K. Bhambra and Robbie Shilliam (Basingstoke: Palgrave Macmillan, 2009 ), 166.

90 Janine N. Clark, Serbia in the Shadow of Milošević: The Legacy of Conflict in the Balkans (London: Tauris Academic Studies, 2008).

91 Das and Kleinman, supra $\mathrm{n} 85$ at 1.

92 Kidron, supra $\mathrm{n} 6$.

93 See, Andrej Nosov, Serbia and Srebrenica 1995-2005 (Belgrade: Youth Initiative for Human Rights, 2006).

94 Personal interview, N.C., Belgrade, Serbia, 22 March 2006.

95 Kidron, supra $\mathrm{n} 6$.

96 Wilkinson, supra n 11; Hansen, supra n 62.

97 See, Kidron, supra $n 6$.

98 Personal interview, K.S., Belgrade, Serbia, 14 April 2006.

99 Personal interview, N.M., Belgrade, Serbia, 26 May 2006.

100 Personal interview, B.S., Belgrade, Serbia, 2 March 2006.

101 Personal interview, R.M., Belgrade, Serbia, throughout October 2005 until June 2006.

102 Belgrade Centre for Human Rights, 'Crimes and Punishment in the Minds of People - The Internalisation of the ICTY Legacy,' http://english.bgcentar.org.rs/index.php?option=com_content\&view=article\&id=737\%3Acrimes-and-punishment-in-the-minds-of-people-theinternalisation-of-the-icty-legacy\&catid=155\&ltemid=68 (accessed 27 March 2013).

103 Belgrade Centre for Human Rights, "'News from the Past" - Historical Illusions: Misconceptions about the Past and Their Social and Political Effects,' http://english.bgcentar.org.rs/index.php?option=com_content\&view=article\&id=553\%3A2009-news-from-the-pasthistorical-illusions-misconceptions-about-the-past-and-their-social-and-political-effects-link\&catid=155\&ltemid=140 (accessed $27 \mathrm{March}$ 2013).

104 Orentlicher, supra n 3.

105 See, Hansen, supra n 62.

106 Simpson, supra n 61 at 482. 
107 Personal interview, B.S., Belgrade, Serbia, 2 March 2006.

108 Personal interview, J.N., Belgrade, Serbia, 13 August 2006.

109 Jelena Subotić, 'Expanding the Scope of Post-Conflict Justice: Individual, State and Societal Responsibility for Mass Atrocity,' Journal of Peace Research 48(2) (2011): 161.

110 James C. Scott, 'Everyday Forms of Resistance,' Copenhagen Journal of Asian Studies 4 (1989): 33-62.

111 Personal interview, M.D., Belgrade, Serbia, 5 June 2006.

112 Wilkinson, supra n 11.

113 Personal interview, S.P., Belgrade, Serbia, 4 April 2006.

114 Kidron, supra $n 6$.

115 Zerubavel, supra n 47.

116 See, Daniel, supra n 42.

117 Personal interview, R.M., Belgrade, Serbia, 24 May 2006.

118 Daniel, supra n 42.

119 Elaine Scarry, The Body in Pain: The Making and Unmaking of the World (New York: Oxford University Press, 1985).

120 Michael Taussig, 'Terror as Usual: Walter Benjamin's Theory of History as a State of Siege,' Social Text 23 (1989): 3-20.

121 Valentine E. Daniel, Is There a Counterpoint to Culture? (Amsterdam: Wertheim Lecture Center for Asian Studies, 1991).

122 For example, Patricia B. Hayner, Unspeakable Truths: Transitional Justice and the Challenge of Truth Commissions, 2nd ed. (London: Routledge, 2011).

123 Lila Abu-Lughod, 'Do Muslim Women Really Need Saving? Anthropological Reflections on Cultural Relativism and Its Others,' American Anthropologist 104(3) (2002): 784. The original example is 'the-Taliban-and-the-Terrorists.'

124 Johanna Mannergren Selimović, 'Perpetrators and Victims: Local Responses to the International Criminal Tribunal for the Former Yugoslavia,' Focaal 10(57) (2010): 50-61.

125 Cillian McGrattan, “'Order Out of Chaos”: The Politics of Transitional Justice,' Politics 29(3) (2009): 164-172.

126 Ibid.

127 Olivera Milosavljević, Tačka razlaza: Povodom polemike vodjene na stranicama lista Vreme od 1. avgusta do 21. novembra 2002, Helsinške Sveske 16 (Belgrade: Helsinki Committee for Human Rights, 2003).

$128 \mathrm{lbid}$.

129 Stef Jansen, 'The Violence of Memories: Local Narratives of the Past after Ethnic Cleansing in Croatia,' Rethinking History 6(1) (2002): 7793.

130 Personal interview, N.M., Belgrade, Serbia, 26 May 2006.

131 Personal interview, K.S., Belgrade, Serbia, 14 April 2006.

132 McGrattan, supra n 125.

133 Ibid., 168.

134 See, for example, Laura J. Shepherd, “Victims, Perpetrators and Actors” Revisited: Exploring the Potential for a Feminist Reconceptualisation of (International) Security and (Gender) Violence,' British Journal of Politics and International Relations 9(2) (2007): 239256.

135 McGrattan, supra n 125 at 168 . 
136 See, Donnan and Simpson, supra n 58.

137 Alejandro Castillejo Cuéllar, 'Unravelling Silence: Violence, Memory and the Limits of Anthropology’s Craft,' Dialectical Anthropology 29(2) (2005): 161.

138 Ibid.

139 Kostovicova, supra n 73, drawing on Robert Putnam, Making Democracy Work: Civic Traditions in Modern Italy (Princeton, NJ: Princeton University Press, 1993).

140 Personal interview, F.S., Belgrade, Serbia, 17 August 2006.

141 Personal interview, V.T., Belgrade, Serbia, 8 July 2006.

142 West, supra $\mathrm{n} 14$.

143 Hansen, supra n 62.

144 Donnan and Simpson, supra n 58.

145 Upendra Baxi, 'Epilogue: Whom May We Speak For, With and After? Re-Silencing Human Rights,' in Silencing Human Rights: Critical Engagements with a Contested Project, ed. Gurminder K. Bhambra and Robbie Shilliam (Basingstoke: Palgrave Macmillan, 2009 ), 253.

146 lbid.

147 Thiesmeyer, supra $\mathrm{n} 9$.

148 Hansen, supra n 62. 